\section{Microbiological stability of canned tuna produced in Italy and in non-European countries}

\author{
Francesco Casalinuovo, ${ }^{1}$ Teresa Gazzotti, ${ }^{2}$ \\ Paola Rippa, ${ }^{1}$ Lucia Ciambrone, ${ }^{1}$ \\ Rosanna Musarella, ${ }^{1}$ Elena Pratticò ${ }^{1}$ \\ ${ }^{1}$ Institute for Experimental Veterinary \\ Medicine of Southern Italy, Catanzaro; \\ 2Department of Veterinary Medical \\ Sciences, University of Bologna, Ozzano \\ dell'Emilia (BO), Italy
}

\section{Abstract}

The results of a study on the microbiological stability of canned tuna produced by Italian companies and similar canned products manufactured in countries outside Europe are reported herein. The study involved 38 samples of canned tuna of various brands, of which 14 were produced by companies outside Europe and 24 by Italian companies. Qualitative and quantitative microbiological tests were conducted for the following parameters: bacterial colony counts at $30^{\circ} \mathrm{C}$, total coliforms, total Enterobacteriaceae, sulphite-reducing anaerobes, Salmonella spp., Bacillus cereus, Escherichia coli, Staphylococcus aureus, yeasts and molds. Bacterial loads and mold contamination were respectivelyin found in 8/14 (57\%) samples from outside EU and 7/24 (29\%) Italian samples. The bacterial flora was represented by Gram-positive bacteria (Staphylococcus warneri, Staphylococcus lentus, Streptococcus mitis, Enterococcus faecalis, Leuconostoc mesenteroides), Gram-negative bacteria (Sphingomonas paucimobilis, Acinetobacter iwoffii, Rhizobium radiobacter), spore-forming bacteria (Bacillus vallismortis), while the fungal species was represented by Penicillium spp., Rhizopus spp., Rhodotorula spp. and Alternaria spp. Excluding anomalies in the thermal treatment process of products and any contamination after treatment, the contaminations encountered in both cases were most likely due to insufficient production quality standards and the quality of the raw material used. These results may require a redefinition of the concept of commercial stability as hitherto stated.

\section{Introduction}

Globally, the production of canned tuna is continuously increasing and the current European market demand far exceeds the availability of raw material that the fishing areas of the European Union (EU) are able to provide, forcing fish processing companies to seek new and cheaper sources of supply, such as zero duty Africa, Caribbean and Pacific (ACP) countries. There are therefore considerably increased imports of tuna from countries such as the Ivory Coast, Mauritius and Papua New Guinea and, with regard to Italy, also from the Seychelles (+48\%) (FA0, 2014), with Italian processing companies increasingly supplied by fish from non-European waters (Aniol and Rupert, 2011). According to a study by the Ministry of Agriculture, Fisheries and Food of the Spanish Government (Interatun, 2007), the EU's decision to lower the $12 \%$ tax on the importation of fish products from some nonEuropean countries, has significantly reduced the competitiveness of European fishing. Moreover, the checks carried out on imported products are not exhaustive and do not always meet all the parameters set by European legislation, in particular Regulations (CE) 853/2004, 854/2004, 882/2004 and 558/2010, with the consequent risk that the raw material is not of good quality and that the sterilisation processes normally used in the canning industry may be insufficient to eliminate the microbiological contamination present at the time of processing (Landry et al., 1998; Warne, 1988). The level of tuna meat contamination is influenced by the environment and the conditions and methods of fishing, time of year, handling, processing and evisceration, but particularly by the handling on board and the delayed cooling of fish during storage and transfer at markets and processing plants (Figueroa et al., 2006; Grau et al., 2003; Doyle et al., 2000). Several research studies have examined the stability of canned fish (Ali et al., 2008; Figueroa et al., 2006; Gonzales et al., 1997), but there are no specific studies on the difference in stability between the same type of canned products manufactured in different production and commercial environments. On the basis of this assumption, we perfomed a study on the comparision of the microbiological stability of canned tuna produced in Italy and that manufactured by outside EU processing companies. The investigation covered microbiological laboratory analytical controls, aimed at verifying the presence of bacterial and fungal contamination in a number of commercial samples of canned tuna produced partly in Italy and partly in non-European countries and purchased at food retailers during the commercial phase of the food chain.

\section{Materials and Methods}

Thirty-eight samples of canned tuna in oil from various brands available on the market in some Italian regions, were analysed in packs
Correspondence: Francesco Casalinuovo, Institute for Experimental Veterinary Medicine of Southern Italy, viale Crotone snc, 88100 Catanzaro, Italy.

Tel. +39.0961.737763 - Fax: +39.0961 .738088 .

E-mail: francesco.casalinuovo @cert.izsmportici.it

Key words: Canned food, Canned tuna, Food safety, Food technology.

Conflict of interest: the authors declare no potential conflict of interest.

Received for publication: 16 October 2014

Revision received: 4 February 2015.

Accepted for publication: 4 February 2015.

This work is licensed under a Creative Commons Attribution 3.0 License (by-nc 3.0).

CC Copyright F. Casalinuovo et al., 2015

Licensee PAGEPress, Italy

Italian Journal of Food Safety 2015; 4:4780

doi:10.4081/ijfs.2015.4780

of 80 and $125 \mathrm{~g}$, of which 14 samples were manufactured in non EU factories and marketed on EU markets, while the other 24 were manufactured in Italian factories and sold $n$ markets outside EU. Samples from outside Europe came from Ivory Coast, Colombia, Perù, Ecuador, Thailand, Mauritius, Indonesia and Seychelles. The 24 samples of tuna manufactured in Italy, belonging to the most popular brands, were from 5 of the most famous canning companies in the domestic market, which will be indicated by letters of the alphabet A, B, C, D and E. Samples were displayed on shop shelves for sale at room temperature, before being identified and selected according to the purpose of the investigation. Each sample was composed of at least 6 packs of canned tuna in olive oil, of which three were used for testing pre-incubation and three were incubated at $35^{\circ} \mathrm{C}$ for 21 days. During incubation, the samples were checked daily to identify possible impairment (loss of content, can swelling, etc.), but no samples were removed for these reasons before testing began. The samples to be analysed, both those incubated and those non-incubated, were first subjected to a thorough cleaning and cleansing of the external surface of the containers and subsequently disinfected with a $5 \%$ chlorine solution. All packaging was equipped with ring pull opening, practiced in sterile conditions under a laminar flow hood. Once collected, the samples were subjected to a series of qualitative and quantitative microbiological tests for verification of the possible presence of bacterial and fungal contamination. We proceeded to draw $10 \mathrm{~g}$ of content from each sample, diluted in 90 $\mathrm{mL}$ of saline solution and subsequently homogenised for $2 \mathrm{~min}$, with the final prepara- 
tion of decimal dilutions for quantitative tests, while $25 \mathrm{~g}$ of matrix was added to $225 \mathrm{~mL}$ of peptone water for Salmonella spp. testing. The microbiological parameters determined for each sample and the related test methods used were as follows: Survey of Salmonella spp. (UNI, 2004a), total plate count (TPC) Horizontal method for the enumeration of microorganisms - Colony count at $30^{\circ} \mathrm{C}$ technique (UNI, 2013), enumeration of Bacillus cereus (UNI, 2005), enumeration of coliforms (ISO, 2006), enumeration of E.coli (ISO, 2001), enumeration of Enterobacteriaceae (ISO, 2004), enumeration of coagulase-positive staphylococci (UNI, 2004b), enumeration of yeasts and molds (ISO, 2008), enumeration of sulfite-reducing bacteria growing under anaerobic conditions (ISO, 2003). For the specific bacterial colonies developed on the culture media used for counting bacterial colonies (CBC) at $30^{\circ} \mathrm{C}$, subcultures were carried out on Columbia agar base (Biolife) supplemented with defibrinated sheep blood and subsequently subjected to Gram staining and identification through biochemical testing with an automated system (VITEK 2TM Compact; bioMérieux, Marcy l'Etoile, France). The identification of mold was obtained using morphology and colouring of the colonies, direct microscopic observation and staining with Amman's lactophenol/fuchsin lactophenol. Before and after pre-incubation at $30^{\circ} \mathrm{C}$ for 15 days, a pH measurement (ISO, 1999) was also carried out for all samples.

\section{Results}

The inspection tests and pre-analytical checks conducted on the containers and content of all 38 samples did not show any abnormality of organoleptic characteristics or outer casing sealing, both in the incubated samples and in those not incubated. Table 1 shows that the samples of canned tuna in olive oil from outside the EU do not conform to the microbiological tests performed.

In 8/14 non-EU samples (57\%) TPC values between 10 and $10^{6} \mathrm{CFU} / \mathrm{g}$ were found, as well as the presence of molds in 5/14 samples (35.7\%) with mean values of contamination of $2860 \mathrm{CFU} / \mathrm{g}$. Bacterial and fungal contamination was detected simultaneously in 3 samples. In particular, the sample n.3 presented TPC values of $280 \mathrm{CFU} / \mathrm{g}$ already in the non-incubated product, while the post-incubation checks showed levels of TPC to be $10^{6} \mathrm{CFU} / \mathrm{g}$, with the simultaneous presence of $10^{4} \mathrm{CFU} / \mathrm{g}$ of mold. No level of contamination was found in 6/14 samples. Among the individual bacterial species constituting the contaminating flora, Gram-positive bacteria such as Enterococcus faecalis (120 CFU/g) in one sample and Staphylococcus warneri (20 CFU/g) in one sample, Gram-negative bacteria such as
Rhizobium radiobacter (Agrobacterium tumefaciens) in two samples and spore-forming bacteria such as Bacillus vallismortis in one sample were observed. Among the fungi Penicillium spp., Rhizopus spp. and Rhodotorula spp. were observed. Still, with regard to testing on non-EU products, quantitative microbiological tests were performed for sulphite-reducing anaerobes, total Coliforms, total Enterobacteriaceae and qualitative microbiological tests for Salmonella spp., Bacillus cereus, E. coli and Staphylococcus aureus, all of which constantly gave a negative outcome. As regards the canned tuna produced in Italy (Table 2), the samples produced from 3 of the 5 fish processing companies considered (Companies C, D and E) were free of bacterial and fungal contamination (negative TPC preincubation and post-incubation, negative yeasts and molds numbers, negative detection of pathogens). In 2 samples produced by Company A and in 5 produced by Company B, however, high values of TPC were recorded and one case also showed fungal contamination. Among the mesophilic bacterial flora, Gram-negative bacteria (Sphingomonas paucimobilis and Acinetobacter iwoffii) and Granpositive bacteria (Streptococcus oralis) were observed. In the light of these results, another 3 samples of the product of a different batch and production date were performed, which showed a complete absence of any level of bacterial and fungal contamination. For Company

Table 1. Samples of canned tuna fish produced outside Europe that proved to be non-standard on microbiological testing.

\begin{tabular}{lll} 
Samples & Non-standard data pre-incubation & Non-standard data post-inculbation \\
1 & - & TPC 5200 CFU/g; moulds 1000 CFU/g; presence of Bacillus vallismortis \\
2 & - & TPC $104,000 \mathrm{CFU} / \mathrm{g}$ \\
\hline 3 & TPC $280 \mathrm{CFU} / \mathrm{g}$; presence of Enterococcus faecalis & TPC 1,000,000 CFU/g; moulds 10,000 CFU/g \\
4 & - & TPC $20 \mathrm{CFU} / \mathrm{g} ;$ moulds $1000 \mathrm{CFU} / \mathrm{g}$; presence of Staphylococcus warneri \\
\hline 5 & - & Moulds $2000 \mathrm{CFU} / \mathrm{g}$ \\
6 & - & TPC $10 \mathrm{CFU} / \mathrm{g} ;$ presence of Rhizobium radiobacter \\
\hline 7 & - & Moulds $300 \mathrm{CFU} / \mathrm{g}$ \\
8 & - & TPC $3000 \mathrm{CFU} / \mathrm{g} ;$ presence of Rhizobium radiobacter
\end{tabular}

Table 2. Samples of canned tuna produced in Italy that proved to be non-standard on microbiological testing.

\begin{tabular}{lll} 
Samples & Non-standard data pre-incubation & Non-standard data post-incubation \\
1 (producer B) & - & Moulds $100 \mathrm{CFU} / \mathrm{g}$ \\
2 (producer A) & - & TPC 2,727 CFU/g; presence of Sphingomonas paucimobilis \\
\hline 3 (producer A) & - & TPC $291 \mathrm{CFU} / \mathrm{g} ;$ presence of Streptococcus mitis/oralis and Acinetobacter iwoffii \\
4 (producer B) & - & TPC $109,091 \mathrm{CFU} / \mathrm{g}$ \\
\hline 5 (producer B) & - & TPC 1,236,364 CFU/g \\
6 (producer B) & - & TPC 1,209,091 CFU/g \\
\hline 7 (producer B) & - & TPC 3091 CFU/g; presence of Staphylococcus lentus and Leuconostoc \\
& & mesenteroides spp. cremoris \\
\hline
\end{tabular}

TPC, total plate count; CFU, colony forming units. 
B, 13 different samples were tested, of which 5, from a different batch and production date, were contaminated with values post-incubation between $10^{2}$ and $10^{6} \mathrm{CFU} / \mathrm{g}$ and a fungal load of $100 \mathrm{CFU} / \mathrm{g}$.

Among the bacterial species present, Staphylococcus lentus and Leuconostoc mesenteroides were observed, while among the fungi there were Penicillium spp. and Alternaria spp. As with the non-EU products, tests were performed on all Italian production samples for the detection of Salmonella spp., Bacillus cereus, E. coli and Staphylococcus aureus, as well as the determination of total coliforms, sulphite-reducing anaerobes and enumeration of Enterobacteriaceae, all of which gave consistently negative results. Lastly, a measurement of $\mathrm{pH}$ values was performed on all Italian and non-EU samples, which gave values consistently between 5.8 and 6.5 .

\section{Discussion}

The first important fact to consider is that more than $1 / 3(39.4 \%)$ of the samples of canned tuna examined were contaminated with bacteria and fungi in the microbiological tests performed after an incubation period of 15 days at $30^{\circ} \mathrm{C}$, thus not being compatible with the specific criteria laid down by Regulation (CE) 882/2004 (European Commission, 2004c) and Directive 97/78/CE (European Commission, 1997). In fact, preincubation tests revealed bacterial and fungal contamination in only one sample (280 $\mathrm{CFU} / \mathrm{g}$ ), while in the other samples contaminated in the subsequent post-incubation tests, contamination was likely present in such low concentrations to be undetectable with the microbiological methods used. Another important aspect is the absence of the main pathogenic bacteria responsible for food-borne outbreaks, since contaminations were supported in some cases by bacterial and fungal species with non-pathogenic effects in humans or animals (Bacillus vallismortis, Rhizobium radiobacter) (Logan and De Vos, 2009; Hood et al., 1986), or in some circumstances, responsible for various human diseases such as urinary tract infections, bacteremia, endocarditis, and meningitis (Enterococcus faecalis), or infections in patients with an impaired immune system (Staphylococcus warneri), (Kamath et al., 1992), nosocomial infections (Sphingomonas paucimobilis, Streptococcus mitis/oralis, Leuconostoc mesenteroides) (Shelburne et al., 2014; Ryan and Adley 2010; Bou et al., 2008), and acute gastroenteritis (Acinetobacter iwoffii) (Nora and Greg, 2009). Among the species identified and in addition to human infections, only Staphylococcus lentus was also associated with subclinical mastitis in sheep (Schwendener and Perreten, 2012). By then comparing the test results obtained from samples of canned tuna manufactured outside Europe and in Italy, the assessments must necessarily take into account that the same type of product has been used, although it is manufactured and sold in different social, productive and commercial contexts. If we exclude abnormalities in the thermal treatment process of products and possible contamination after treatment for both production contexts, the results may indicate problems of contamination along the production line or in the use of raw materials with such a high level of contamination to be completely inactivated by the thermal treatment of $116^{\circ} \mathrm{Cx} 30 \mathrm{~min}$, as normally used in the production of canned tuna. In both cases, these conditions inevitably affect the stability of the final product. The quality of the raw material might also explain the varied results found in different production batches manufactured by the same company. The contamination of $7 / 24$ Italian samples (29\%) and 8/14 non-EU samples $(57 \%)$ represent negative datas and probably lead us to reconsider the concept of commercial stability of canned products as enunciated so far, especially in reference to the nonEU sample that was found already contaminated in the pre-incubation tests and also according to similar results previously obtained by other authors (Ali et al., 2008).

\section{Conclusions}

This research has revealed the existence of a bacterial and fungal contamination in canned tuna in olive oil commonly found in the market, both of Italian and non-EU origin. If the risk could be hypothesised for the non-EU canned products, because of the rules, of the productive standards and of the less strict food security criteria in the countries from which these samples come from; this risk does not exist for Italian canned products thanks to the very good productive level and the established tradition of the Italian canning industry, as well as the strict and effective national and EU regulation in force concerning food safety, such as Regulations (EC) of the so called Hygiene Package and subsequent amendments. If we exclude abnormalities of the production process, the risk of contamination of canned products may derive from the quality of health conditions of the raw materials used. The quality levels of raw materials for fish processing industries do not always correspond sufficiently to the advantageous cost proposed by the international market for the supply thereof. This may also explain the irregularities found in the official checks on contamination prevention and food safety, resulting in the activation of the national alert system and in some cases even on a European level. Hence, the need for a more incisive monitoring of the import of fresh or frozen tuna intended for processing by the canning industry. Lastly, the authors repent the need to reconsider the concept of commercial stability applied to canned products.

\section{References}

Ali EAWM, Othmun RM, Alhafeth TA, 2008. Microbial evaluation of canned meat. AlQadisiya J Vet Med Sci 2008;7:10-3.

Aniol E, Rupert C, 2011. Fish dependence: 2011. Update: the increasing reliance of the EU on fish from elsewhere. New Economics Foundation, London. Available from: http://greennewdeal.eu/ agriculture/publications/2011/en/fish-dependence-the-increasing-reliance-of-the-euon-fish-from-elsewhere.html

Bou G, Saleta JL, Sáez Nieto JA, Tomás M, Valdezate S, Sousa D, Lueiro F, Villanueva R, Pereira MJ, Llinares P, 2008. Nosocomial outbreaks caused by leuconostoc mesenteroides. Emerg Infect Dis 2008;14:968-71.

Doyle M, Beuchat L, Montville T, 2000. Microbiología de los alimentos: fundamentos y fronteras. Acribia, Zaragoza, Spain.

European Commission, 1997. Council Directive of 18 December 1997 laying down the principles governing the organisation of veterinary checks on products entering the Community from third countries, 97/78/EC. In: Official Journal, L 24/9, 30.1.98

European Commission, 2004a. Regulation of the European Parliament and of the Council of 29 April 2004 laying down specific hygiene rules for on the hygiene of foodstuffs, 853/2004/EC. In: Official Journal, L 139/55, 30.4.2004.

European Commission, 2004b. Regulation of the European Parliament and of the Council of 29 April 2004 laying down specific rules for the organisation of official controls on products of animal origin intended for human consumption, 854/2004/EC. In: Official Journal, L 226/83, 25.6.2004.

European Commission, 2004c. Regulation of the European Parliament and of the Council of 29 April 2004 on official controls performed to ensure the verification of compliance with feed and food law, animal health and animal welfare rules, 882/2004/EC. In: Official Journal, L 165, 30.4.2004.

European Commission, 2010. Commission Regulation of 24 June 2010 amending Annex III to Regulation (EC) No 853/2004 of the European Parliament and of the 
Council laying down specific hygiene rules for food of animal origin, 558/2010/EU. In: Official Journal, L 159/18, 25.6.2010.

FA0, 2014. Globefish market report. Tuna: January 2014. Available from: http://www.globefish.org/tuna-january2014.html

Figueroa YdVM, Cabello AM, Villalobos LB, Guevara G, Figuera García BE, Vallenilla González OM, 2006. Cambios físicos-químicos y microbiológicos observados durante el proceso tecnológico de la conserva de atún. Zootec Trop 24:17-29.

Gonzalez MA, Estupinan S, Millan R, Sanjuan E, Mangas JM, 1997. Contribution to the study of canned tuna in oil: I. Physical-chemical and stability components. Alimentaria 35:71-5.

Grau CD, Sánchez A, Zerpa 0, Vallenilla Y, Berti 0, 2003. Estudio de la microflora asociada a la formación de histamina en sardina (Sardinella aurita). Rev Fac Cien Vet LUZ 13:199-204.

Hood EE, Helmer GL, Fraley RT, Chilton MD, 1986. The hypervirulence of Agrobacterium tumefaciens A281 is encoded in a region of pTiBo542 outside of T-DNA. J Bacteriol Dec 1986;1291-301.

Interatun, 2007. Estudio de la calidad de las conservas de túnidos procedentes del sudeste asiático comercializadas en la Unión Europea. Interatun, Vigo, Spain.

ISO, 1999. Meat and meat products. Measurement of $\mathrm{pH}$. Reference method. Norm ISO 2917:1999. International Organization for Standardization ed., Geneva, Switzerland.

ISO, 2001. Microbiology of food and animal feeding stuffs. Horizontal method for the enumeration of beta-glucuronidase-positive Escherichia coli. Part 2: Colony-count technique at 44 degrees $\mathrm{C}$ using 5-bromo4-chloro-3-indolyl beta-D-glucuronide. Norm ISO 16649-2:2001. International Organization for Standardization ed., Geneva, Switzerland.
ISO, 2003. Microbiology of food and animal feeding stuffs. Horizontal method for the enumeration of sulfite-reducing bacteria growing under anaerobic conditions. Norm ISO 15213:2003. International Organization for Standardization ed., Geneva, Switzerland.

ISO, 2004. Microbiology of food and animal feeding stuff. Horizontal methods for the detection and enumeration of Enterobacteriaceae. Norm ISO 215282:2004. International Organization for Standardization ed., Geneva, Switzerland.

ISO, 2006. Microbiologia di alimenti e mangimi per animali. Metodo orizzontale per la numerazione di Coliformi. Tecnica della conta delle colonie. Norm ISO 4832:2006. International Organization for Standardization ed., Geneva, Switzerland.

ISO, 2008. Microbiologia di alimenti e mangimi per animali. Metodo orizzontale per la numerazione di lieviti e muffe. Parte 1: Tecnica della conta delle colonie. Norm ISO 21527-1:2008. International Organization for Standardization ed., Geneva, Switzerland.

Kamath U, Singer C, Isenberg HD, 1992. Clinical significance of Staphylococcus warneri bacteremia. J Clin Microbiol 30:261-4.

Landry WL, Schwab AH, Lancette GA, 1998. Examination of canned foods. In: Merker RL, ed. Food and Drug Administration bacteriological analytical manual. AOAC International, Gaithersburg, MD, USA.

Logan NA, De Vos P, 2009. Genus I. Bacillus Cohn 1872. In: De Vos P, Jones G, Krieg NR, Ludwing W, Rainey FA, Schleifer KH, Whitman WB, eds. Bergey's manual of systematic bacteriology. 2nd ed. Springer, New York, USA, pp 21-128.

Nora GR, Greg M, 2009. Acinetobacter lwoffii: bacteremia associated with acute gastroenteritis. Travel Med Infect Dis 7:316-7.

Ryan MP, Adley CC, 2010. Sphingomonas paucimobilis: a persistent Gram-negative nosocomial infectious organism. J Hosp Infect 2010;75:153-7.

Schwendener S, Perreten V, 2012. New MLS Resistance Gene erm(43) in Staphylococcus lentus. Antimicrob. Agents Chemother 56:4746-52.

Shelburne SA, Sahasrabhojane P, Saldana M, Yao H, Su X, Horstmann N, Thompson E, Flores AR, 2014. Streptococcus mitis strains causing severe clinical disease in Cancer Patients. Emerg Infect Dis 20:76271.

UNI, 2004a. UNI EN ISO Norm 6579:2004. [Microbiologia di alimenti e mangimi per animali - Metodo per la ricerca di Salmonella spp]. [Regulation in Italian]. Italian Unification Institute ed., Milan, Italy.

UNI, 2004b. UNI EN ISO Norm 6888-1:2004. [Microbiologia di alimenti e mangimi per animali - Metodo per la conta di Stafilococchi coagulasi positivi (Staphylococcus aureus e altre specie) Tecnica che utilizza il terreno agar BairdParker]. [Regulation in Italian]. Italian Unification Institute ed., Milan, Italy.

UNI, 2005. UNI EN ISO Norm 7932:2005a. [Microbiologia di alimenti e mangimi per animali - Metodo orizzontale per la conta di Bacillus cereus - Tecnica della conta delle colonie a $30^{\circ} \mathrm{C}$ ]. [Regulation in Italian]. Italian Unification Institute ed., Milan, Italy.

UNI, 2013. UNI EN ISO Norm 4833-1:2013. [Microbiologia di alimenti e mangimi per animali - Metodo orizzontale per la conta di microrganismi - Tecnica della conta delle colonie a $30^{\circ} \mathrm{C}$ ]. [Regulation in Italian]. Italian Unification Institute ed., Milan, Italy.

Warne D, 1988. Thermal destruction of bacteria. Manual on fish canning. Available from: http://www.fao.org/docrep/003/ t0007e/t0007e00.HTM 